\title{
Optimization of Selected Agricultural Export Commodities to Improve Indonesia's Weaponry Countertrade
}

\author{
Zainal Arifin", Agus Suman and Moh. Khusaini
}

Faculty of Economics and Business Universitas Brawijaya, Malang 65300, Indonesia

\begin{abstract}
In an increasingly open global economy, international trade, including exports, is an inseparable part of economic activity between countries. This paper aims to analyze the choice of commodities that have the potential to encourage the implementation of defense equipment trade-in Indonesia along with some optimization efforts. Using the literature review and library research by exploring data of national agricultural export and arms trade, this article identifies selected commodities that have the potential to be exchanged with defense equipment in trade returns, and also attempts to optimize exports to encourage the implementation of trade returns themselves. The results showed that trade return is one of the schemes in international trade in the form of two-way sales. The weaponry system is a strategic product that is still imported by Indonesia from abroad so that it has the potential to be implemented in a trade return scheme. On the other hand, Indonesia is known to excel in agricultural products, especially the plantation subsector, and has succeeded in becoming the top exporters for many agricultural commodities in the global market.
\end{abstract}

Keywords: Exports, superior commodities, trade returns, defense equipment.

\section{INTRODUCTION}

Globalization has substantially changed international relations by reducing trade and investment barriers and creating competition in the economies of various countries (Donoso, 2016). The dynamic interaction of exports and imports has increased the level of economic interdependence relations while sharpening competitiveness between countries, not only in international trade, but also in the flow of investment, finance, and production (Tambunan, 2004). Economic openness, if utilized optimally, will enhance its main growth prospects for developing countries. One of the special products traded between countries is the main tool of the weapons system/defense equipment. In international trade, forms of transactions between countries can be divided into two: one-way transactions and two-way transactions. In a one-way transaction, when two countries trade, one party will act as a producer/exporter and the other party acts as a consumer/importer. In two-way transactions, one party will have two roles, namely producers as well as consumers. This form of two-way trade can be found in the trade return scheme because it contains the principle of bilateral compensation (Halbach and Osterkamp, 1989; Arifin et al., 2020).

A trade-off transaction, commonly known as countertrade, refers to a transaction in which the seller provides goods to the buyer and contractually agrees to also buy goods from the same party with an agreed

*Address correspondence to this author at the Faculty of Economics and Business, Universitas Brawijaya, JI. MT. Haryono 165, Malang, East Java 65300, Indonesia; Tel: 0341-555000; Fax: 0341-553834;

E-mail: zlarif260@gmail.com percentage of the value of the initial sales contract (Hennart and Anderson, 1993). The distinguishing characteristic of other trades is that trade returns have a form of barter-type transactions. Generally, the goods offered by developing countries in trade include raw materials, but their range of products is now developing rapidly to include not only intermediate and finished products but also various types of services. Commodities and semi-finished products that are usually offered typically include mineral, metal, petroleum, steel, cement, fertilizer, coffee, cocoa, rubber, and palm oil (Halbach and Osterkamp, 1989).

Despite having great economic opportunities, the implementation of trade returns in Indonesia has not yet reached maximum results. For example on the purchase of the SU-35 Sukhoi aircraft from Russia. The purchase value of SU-35, which reached USD 1.14 billion, provides the export potential to Russia for Indonesia by $50 \%$ of the value of the purchase, or worth USD 570 million. One obstacle faced was the selection of commodities that were proposed as part of trade returns. In the $\mathrm{MoU}$, it was agreed to purchase more than one commodity from Indonesia, with choices in the form of processed rubber and its derivatives, CPO and its derivatives, machines, coffee and its derivatives, cocoa and its derivatives, textiles, tea, footwear, processed fish, furniture, copra, plastics and their derivatives, resins, paper, spices, defense industry products, and other products.

Every year Indonesia is recorded to export more than 100 types of commodities to various countries (UN Comtrade, 2019). Previous literature has shown that increased export flows are engines for economic 
growth (Giles and Williams, 2000; Auboin, 2004; Harrison and Rodriguez-Clare, 2010). The identification of the right commodity is expected to accelerate the trade return process to increase exports. At a macroeconomic level, exports enhance a country's economy and welfare and significantly influences exchange values as well as fiscal and monetary policies (Czinkota, 2002) and contribute to employment, trade balance, economic growth, and higher living standards (Lee and Habte Giorgis, 2004). On a micro-economic scale, exports enhance the growth and long-term survival of small and medium-sized businesses (Stoian and Rialp-Criado, 2010). On the other hand, the needs of defense equipment from abroad can be met to maintain the function of the country's sovereignty. Thus, this paper aims to analyze the choice of commodities that have the potential to encourage the implementation of defense equipment trade-in Indonesia along with some optimization efforts.

\section{LITERATURE REVIEW}

\subsection{Counter Trade}

Countertrade is a form of international business behavior in which import transactions are related to reciprocal export transactions (Zurawski and Swechmezan in Fletcher, 1996). Hennart and Anderson (1993) defined countertrade transactions as transactions in which the seller provides the goods to the buyer and contractually agrees to buy goods from the buyer that is equal to the agreed percentage of the value of the initial sales contract. The distinguishing characteristic of other trades is that trade returns have a form of barter-type transactions. Two elements that underlie a country to trade, according to Reisman et al., (1988), are to safeguard currencies and improve the trade balance.

There are several forms of trade returns including barter, counter purchase, offset, and buy-back. Countertrade is different from other forms of international trade because of the relatively long period required in negotiations (large transaction value and a number of parties involved), more complex (many things required in transactions), and the presence of government involvement (Fletcher, 1996). Trade return is a form of procurement mechanism for foreign defense and security equipment in addition to local content and offsets. The form of procurement from abroad is not merely the purchase of defense and security equipment, but also in the form of repairs and maintenance because in the country its ability is still limited in carrying out repairs and maintenance on its own. Trade returns in the procurement of foreign defense and security equipment are made through barter or counter purchase. Provisions regarding the value of trade returns in Indonesia, local content, and offset (IDKLO) are not less than $85 \%$, while local content and offset is not less than $35 \%$.

\subsection{Theory of Comparative Advantage}

The theory of comparative advantage put forward by David Ricardo and states that international trade occurs when there are differences in comparative advantage between countries. Comparative advantage will be achieved if a country can produce more goods and services at a lower cost than other countries. These comparative advantages are distinguished by cost comparative advantage (labor efficiency) and production comparative advantage (labor productivity). In a cost comparative advantage (labor efficiency), a country will benefit from international trade if it specializes in producing and exporting goods where the country can produce more efficiently and importing goods where the country produces relatively less or inefficient. Meanwhile, in production comparative advantage (labor productivity) it can be said that a country will benefit from international trade if it specializes in producing and exporting goods where the country produces more productively and imports goods where the country produces relatively less or not productive. In other words, cost comparative emphasizes that comparative advantage will be achieved if a country produces an item that requires fewer hours of labor compared to other countries so that production efficiency occurs. In other words, in the theory of comparative advantage, a nation can increase its standard of living and income if the country specializes in the production of goods and services that have high productivity and efficiency.

\subsection{Impact of Exports for a Country}

Exporting activities for a country are seen as beneficial because it gives rise to a process of specialization through comparative advantage. Therefore, exports are the target of government policy interventions, for example, interventions to reduce trade barriers and promote exports (Greenaway and Kneller, 2004). Pierre (2014) emphasizes that trade in defense equipment between countries, besides containing economic aspects, is also related to international political and security aspects. Each arms transfer has political consequences for the supplier and 
recipient countries, as well as other parties in the international system. Usually, the transfer causes interdependence between the parties involved. Weapon trading is considered as a symbol of support, friendship, kinship, and convergence of interests between countries because the transfer of defense equipment is part of helping allies, friends, or clients to meet their security requirements.

The government of the supplier country can also use weapons transfers as a political tool for bilateral or multilateral relations. Supplier countries can sell weapons to allies and established countries or refuse to sell to potential opponents, as part of foreign policy principles. In certain cases, weapons can even be donated free of charge, sold at low prices, even funded by suppliers with broader geopolitical objectives (Moraes in Avila et al., 2017). At the same time, the governments of recipient countries try to limit the influence and pressure exerted by arms exporters. The degree of independence of recipient countries usually depends on their domestic and regional circumstances, bargaining capacity and negotiations, and whether or not alternative exporters are available. From an economic standpoint, defense equipment exporters often argue that defense equipment exports because they create economies of scale while exporting countries themselves can promote the export of high value-added goods, foreign exchange earnings, encourage research and development, and help keep costs of the arms industry at a level reason (Peron in Avila et al., 2017). Rapid export growth facilitates capital inflows and technology transfers which encourage rapid economic growth (Radelet in Sultanuzzaman et al., 2019). Next, technological progress will contribute to productivity and strategic economic development. Sophisticated technology can produce goods with fewer inputs and lower complexity (Elster in Sultanuzzaman et al., 2019). Also, there are social benefits of exports in terms of rural growth. In many countries, especially developing countries, many exporters come from rural areas so that export incentives contribute to economic development in rural areas (Donoso, 2016).

\section{RESEARCH METHODS}

This research uses the method of literature study or library research. This research examines or critically reviews knowledge, ideas, or findings contained in the body of academic-oriented literature. The focus of the literature review is to find various theories, principles, or ideas that are relevant for analyzing and solving research questions that are formulated. The nature of this research is descriptive analysis, which is the regular breakdown of data that has been obtained, then given an understanding and explanation so that it can be understood properly by the reader.

\section{INDONESIA'S WEAPON TRADING PARTNER}

According to SIPRI notes, Indonesia trades (imports) with 21 countries with quite diverse transaction values. In the last five years, Indonesia imported the most defense equipment from the UK, with a transaction value of US \$ 701 million, followed by America with a relatively large transaction value of US \$ 662 million. In third place, import transactions with the Netherlands were carried out with a sizable nominal in 2017 of US $\$ 449$ million. Details of import transactions with 21 partner countries can be observed in the table below:

Among the 21 import partner countries of Indonesia, China and South Korea are the two Asian countries that ship defense equipment to Indonesia. The value of transactions with South Korea is quite high, amounting to the US \$ 444 million during the 2014-2018 period, and the value of transactions with China amounting to the US $\$ 185$ million. Of the total transaction value of US \$ 3.6 billion spent by Indonesia during 2014-2018. By analyzing the main trading partner countries that provide defense equipment for Indonesia, it can be determined which commodity options can be submitted for trade returns. The choice of the commodity in question is a commodity that is routinely imported by the country from Indonesia and has a high trade value so that it can offset the price of imported defense equipment.

Among several types of defense equipment imported by Indonesia, aircraft and ships are the two most imported defense equipment, shown by high transaction values over the past five years.

\section{PREFERRED COMMODITY FOR TRADE RETURNS OF MAJOR WEAPON TRADING PARTNERS}

Every year Indonesia exports dozens of types of commodities to each of the weapon trading partner countries listed in the table. To expedite the process of bidding for commodities that will be exchanged for trade, high-value and most imported commodities are selected by the country, which will facilitate the negotiation process. Also, the selection of Indonesian commodities with high trade values will be relatively 
Table 1: Indonesian Defense Equipment Imports by Country of Origin 2014-2018

\begin{tabular}{|c|c|c|c|c|c|c|}
\hline Country & 2014 & 2015 & 2016 & 2017 & 2018 & Total \\
\hline United Kingdom & 598 & 24 & 38 & 41 & 0 & 701 \\
\hline United States & 150 & 82 & 94 & 246 & 90 & 662 \\
\hline Netherlands & 3 & 0 & 0 & 449 & 0 & 452 \\
\hline South Korea & 121 & 3 & 0 & 160 & 160 & 444 \\
\hline German & 85 & 29 & 113 & 76 & 20 & 323 \\
\hline France & 18 & 54 & 37 & 129 & 21 & 259 \\
\hline China & 35 & 41 & 42 & 37 & 30 & 185 \\
\hline Switzerland & 33 & 93 & 0 & 8 & 0 & 134 \\
\hline Australia & 19 & 37 & 22 & 34 & 0 & 112 \\
\hline Brazil & 35 & 35 & 18 & 0 & 0 & 88 \\
\hline Spanish & 32 & 24 & 4 & 0 & 0 & 60 \\
\hline Italy & 8 & 0 & 0 & 28 & 23 & 59 \\
\hline Russia & 54 & 0 & 0 & 0 & 0 & 54 \\
\hline Belgium & 1 & 5 & 4 & 12 & 11 & 33 \\
\hline Canada & 6 & 6 & 2 & 0 & 0 & 14 \\
\hline Sweden & 0 & 8 & 0 & 0 & 0 & 8 \\
\hline Denmark & 0 & 5 & 0 & 0 & 0 & 5 \\
\hline Czechia & 0 & 0 & 4 & 0 & 0 & 4 \\
\hline Ukraine & 0 & 0 & 4 & 0 & 0 & 4 \\
\hline Austria & 0 & 0 & 0 & 1 & 0 & 1 \\
\hline Poland & 0 & 0 & 1 & 0 & 0 & 1 \\
\hline Total & 1188 & 445 & 383 & 1220 & 354 & 3603 \\
\hline
\end{tabular}

Data is Trend Indicator Value (TIV) in million USD Data can be declared 0 because the transaction is less than 0.5 million USD.

Source: Importer/Exporter TIV Tables, SIPRI (2019).

more balanced with the value of imported defense equipment.

\subsection{United Kingdom}

The UK is the 20th largest export market for Indonesia $(0.8 \%$ of Indonesian exports) and the 25 th largest import market for Indonesia $(0.6 \%$ of Indonesian imports) in 2018. Indonesia exported 1.5 billion USD and while Indonesia imports 1.2 billion USD. In the case of trading military equipment, Indonesia has long brought most of its military equipment from the UK. Long before, from 1994 to the end of the 1990s Indonesia bought more than half of its military equipment from Britain. During the first three years of the Labor Government in 1999, 83\% of Indonesia's weapons imports came from the United Kingdom and had sent more than $£ 393$ million of military equipment to Indonesia. In 2001 and 2002, Britain issued more than three-quarters of all EU arms export licenses to Indonesia, with the value of these export licenses responsible for more than half the total financial value of the EU arms agreement to Indonesia. In 2002 two-thirds of arms shipments from the EU to Indonesia originated from the United Kingdom. In 20092018, the UK ranked 4th overall in Indonesia as a defense equipment provider after South Korea, Russia, and the United States, with a total trade value with Britain reaching 691 million USD.

The UK's most imported commodities from Indonesia include footwear (USD 253 million), woven clothing (USD 109 million), electronic components (USD 95 million), knitwear (USD 847 million), while imports of agricultural and processed commodities are the most much of the British imported from Indonesia are wood (USD 159 million), vegetable and animal oils (USD 53 million), rubber and processed products (USD 51 million), fish and crustaceans (USD 44 million), and coffee, tea, and spices (USD 31 million). 


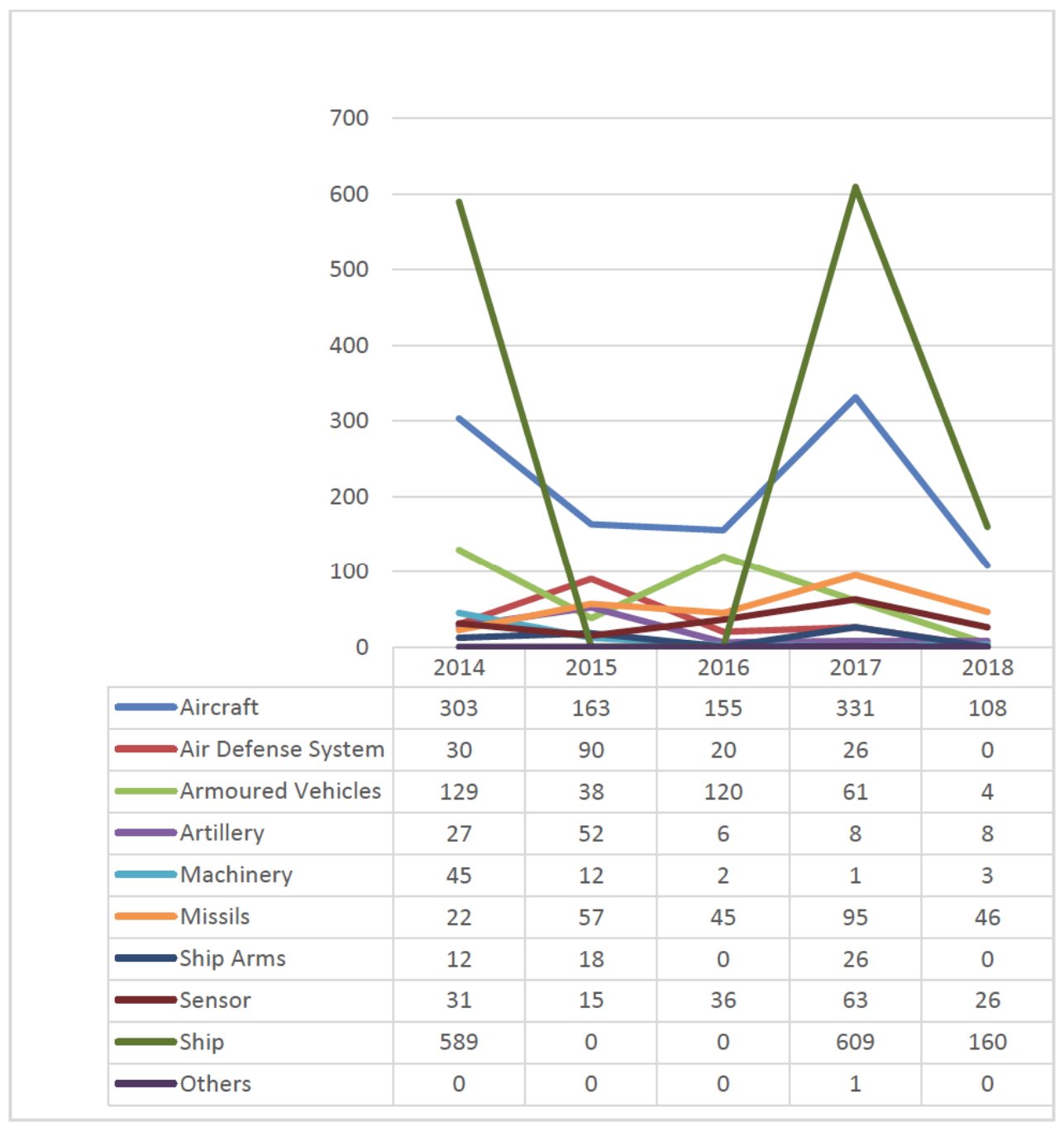

Figure 1: Development of Indonesian Defense Equipment Imports by Type of Goods in 2014-2018.

Source: Importer/Exporter TIV Tables, SIPRI (2019).

\subsection{United States}

The United States and Indonesia agreed on a bilateral Trade and Investment Framework Agreement (TIFA) agreement in 1996 to underpin economic relations between the two. Indonesia is the 34th largest export market for the United States in 2018. The export of US goods to Indonesia in 2018 was USD 8.2 billion, up 19.1\% (USD 1.3 billion) from 2017 and up 44.8\% from 2008. The main export categories in 2018 were various grains (USD 1.1 billion), airplanes (USD 790 million), mineral fuels (USD 683 million), machinery (USD 651 million), and cotton (USD 601 million).

On the other hand, Indonesia is the 23rd largest supplier of imported goods to the United States in 2018. Imports of US goods from Indonesia totaled \$ 20.8 billion in 2018, up 3.1\% (USD 636 million) from 2017 , and up $31,9 \%$ from 2008 . Total imports of US agricultural products from Indonesia amounted to $\$ 3.4$ billion in 2018 including rubber and processed products (USD 1.8 billion), vegetable and animal oils (USD 1.24 billion), coffee, tea, and spices (USD 437 million), fish, and crustaceans (USD 409 million), and wood and processed products (USD 383 million). Then some of these agricultural commodities can become potential commodity options to be exchanged in trade returns.

\subsection{The Netherlands}

The Netherlands is the 12th largest export market for Indonesia (2.2\% of Indonesian exports) with an export value of 3.9 billion USD in 2018 and the 24th largest import market for Indonesia $(0.7 \%$ of Indonesian imports) with an import value of 1.2 billion USD in the same year. In the past 10 years, the total value of Indonesia's defense equipment imports from the Netherlands reached 602 million USD. 
Table 2: Agricultural Commodities Exchange in weapon trade returns between Indonesia and Selected Trade Partners

\begin{tabular}{|c|c|c|c|c|}
\hline Trade Partners & To Indonesia & Code & From Indonesia & Code \\
\hline \multirow[t]{5}{*}{ UK } & Bombs, grenades, bullets & HS 9306900000 & Wood & HS 44 \\
\hline & Artillery & HS 9301100000 & Animal and Animal Fats & HS 15 \\
\hline & Other military weapons & HS 9301900000 & Rubber and its preparations & HS 40 \\
\hline & & & Fish and Crustaceans & HS 16 \\
\hline & & & Coffee, Tea, and Spices & HS 9 \\
\hline \multirow[t]{5}{*}{ US } & Revolvers and Pistols & HS 9302000000 & Rubber and its preparations & HS 40 \\
\hline & Artillery & HS 9301100000 & Animal and Animal Oil & HS 15 \\
\hline & Other military weapons & HS 9301900000 & Coffee, Tea, and Spices & HS 9 \\
\hline & Weapon Partition & HS 9305919000 & Fish and Crustaceans & HS 16 \\
\hline & & & Wood and Processed & HS 44 \\
\hline \multirow{2}{*}{$\begin{array}{c}\text { The } \\
\text { Netherlands }\end{array}$} & Tanks and other combat vehicles & HS 8710 & Animal and Animal Oil & HS 15 \\
\hline & & & Cocoa & HS 18 \\
\hline \multirow[t]{5}{*}{ Russia } & Military weapons and artillery & HS 930110 & Vegetable and animal oils & HS 15 \\
\hline & Tanks and other combat vehicles & HS 8710 & Rubber and its preparations & HS 40 \\
\hline & Grenades, bullets, and other munitions & HS 9306 & Cocoa & HS 18 \\
\hline & & & Coffee, Tea, and Spices & HS 9 \\
\hline & & & Fruits and Nuts & HS 8 \\
\hline \multirow[t]{5}{*}{ Brazil } & Other military weapons & HS 9301900000 & Animal and Animal Oil & HS 15 \\
\hline & Rocket launcher & HS 93012000 & Rubber and its preparations & HS 40 \\
\hline & & & Cocoa & HS 18 \\
\hline & & & Wood and Processed & HS 44 \\
\hline & & & Fruits and Nuts & HS 8 \\
\hline
\end{tabular}

In terms of defense equipment trade, Indonesia is the second-largest defense equipment market for the Netherlands after Jordan. Indonesia is ranked second with a $15 \%$ market share, one of which is from the sale of Damen warships by the Netherlands. During 20142017, Indonesia also brought frigates and radars from the Netherlands. In terms of exports of Indonesian commodities to the Netherlands, Indonesia sends the most chemicals (USD 662 million), electronic components (USD 262 million), food industry waste for animal feed (USD 212 million), cans (USD 198 million), and footwear (USD 166 million). Agricultural and processed commodities that are also widely exported to the Netherlands are vegetable and animal oils (USD 1.009 billion), cocoa (USD 107 million), rubber and processed products (USD 88 million), coffee, tea, and spices (USD 39 million), and fish and crustaceans (USD 34 million).

\subsection{Russia}

Russia is the 28th largest export market for Indonesia ( $0.6 \%$ of Indonesian exports) and the $21 \mathrm{st}$ largest import market for Indonesia $(0.8 \%$ of Indonesian imports) in 2018. The value of Indonesia's exports to Russia in 2018 is 1 billion USD and import value 1.6 billion USD. Russia has sent weapons worth more than 2.5 billion USD to Indonesia over the last 25 years since November 1992. During this period, Russia has sent BTR-80A armored personnel transport vehicles and BMP-3F infantry combat vehicles, series of assault rifles The 100th Kalashnikov, Su-27SK and Su-27SKM, Su-30MK and Su-30MK2 aircraft, Mi-35 and $\mathrm{Mi}-17$ helicopters, as well as weapons systems and other military devices.

In April 2019, Indonesia signed a contract consisting of 21 BT-3F armored amphibious carriers (APC) for $\$$ 67.2 million and 22 BMP-3F infantry combat vehicles (IFVs) for the Marine Corps or KORMAR for USD 108 million, with procurement partly funded from loans as part of an ongoing modernization plan related to the Minimum Essential Force (MEF). The contract was signed by representatives of the Ministry of Defense and Rostec. 
The potential commodities exchanged with Russia for trade are organic chemicals (USD 53 million), electronic components (USD 53 million), footwear (USD 45 million), woven clothing (USD 20 million), and chemical products (USD 15) million). While potential agricultural and processed products include vegetable and animal oils (USD 521 million), rubber and processed products (USD 52 million), cocoa (USD 23 million), coffee, tea and spices (USD 17 million), and fruits and nuts (USD 12 million).

\subsection{Brazil}

Brazil is one of the emerging defense equipment suppliers in the world. UN Comtrade data shows that Brazil exported USD 577 million of light weapons to Southeast Asia between 2014-2016. Of the US \$ 577 million in small arms exports, US \$ 467 million was classified as military firearms aimed at Indonesia, accounting for $80.9 \%$. Brazil and Indonesia maintain bilateral defense ties. The TNI operates several major conventional Brazilian systems, for example, the Avibras Astros II dual rocket launch system (Parameswaran in Picard et al., 2019). Indonesia also signed an agreement to procure components of the rocket launcher system in 2012 (around 36 launchers, plus supporting vehicles), with deliveries starting in 2014 (CAWAT in Picard et al., 2019).

Brazil is the 25th largest export market for Indonesia ( $0.6 \%$ of Indonesian exports) with an export value of 1.1 billion USD and the 19th largest import market for Indonesia (1.0\% of Indonesian imports) with an import value of 1,8 billion USD in 2018. Some of the most potential commodities imported by Brazil from Indonesia are man-made fiber (USD 184 million), vehicles and parts (USD 168 million), electronic components (USD 82 million), nuclear reactors and parts (USD 73 million), footwear (USD 60 million). Then for agricultural commodities, Brazil imports a lot of vegetable and animal oil (USD 205 million), rubber and its processed products (USD 173 million), cocoa (USD 15 million), wood and processed products (USD 9 million), and fruit and nuts (USD 9 million) USD 7.7 million).

\section{OPTIMIZATION OF PREFERRED COMMODITY EXPORTS IN TRADE RETURNS}

The development of agriculture has slowly begun to shift from agricultural food crops to leading plantation crops that support agro-industry, such as oil palm and rubber (Bangun, 2017). Some of the reasons for this shift are due to agro-industry, especially plantation commodities, the opportunity to increase added value, open employment, expand markets for agricultural products, and support efforts to increase income and farmers' welfare. One of the characteristics of agroindustry is that the direction of its development strategy must be based on the area of resource potential approach while still based on the concept of comparative advantage (Nuryati et al., 2018). Therefore, policy for the development of regional agricultural development, especially the plantation sector, is still very much needed to improve the welfare of the farming community.

From the general description above, it can be seen that the agricultural sector with the plantation subsector is very potential, but still needs to be optimized as an alternative to non-monetary financing in the defense equipment trade. Nonetheless, several studies have found that regulatory barriers and import restrictions are a problem for exporting companies or countries (Barker and Kaynak, 1992; Moini, 1997). Barriers to financial and market risk, such as lack of market research or adequate trade prospects, exchange rate risk, or inability to obtain financing for exports have also been cited as obstacles to export. Another study found that transportation costs could hamper exports. Furthermore, export market competition from domestic and foreign suppliers can be a barrier to exporting (Kedia and Chhokar, 1986; Moini, 1997; Shoham and Albaum, 1995; Naidu and Rao, 1993; Barker and Kaynak, 1992).

Export activities generally involve many actors and factors. Some of these are exogenous factors such as natural endowment and historical heritage, but some can be endogenous as well as economic and political choices. These choices form the strategy of developing export which varies from country to country (Ngaruko, 2003). Through the price competitiveness strategy, the government can increase the production of export commodities at lower costs so that they can compete in the international market. Conversely, non-price competitiveness strategies place more emphasis on specialization in products that have good international prospects and can create a niche in new markets, or by shifting national specialization towards more profitable global commodity activities (Ngaruko, 2003). Thus, market forces and export profitability have progressively shifted from upstream activities to downstream specializations (Morrissey and Filatotchev, 2000). 
Likewise, if the export of superior commodities is included in trade returns, the profits obtained are not only goods we need from abroad, but also foreign exchange savings and other multiplier effects. As an illustration, Indonesia is in the process of implementing trade returns in the procurement of the Sukhoi SU-35 with Russia with a value of 1.14 billion USD. In the $\mathrm{MoU}$, it was agreed to purchase more than one export commodity, with choices in the form of processed rubber and its derivatives, CPO and its derivatives, machines, coffee and its derivatives, cocoa and its derivatives, textiles, tea, footwear, processed fish, furniture, copra, plastics and their derivatives, resins, paper, spices, defense industry products, and other products. From the list of commodities above, each export value to Russia is seen as follows: processed rubber and its derivatives (52.78 million USD), CPO and its derivatives (403 million USD), machinery (53.62 million USD), coffee and its derivatives (1.48 million USD), cocoa and its derivatives (23.18 million USD), textiles (20 million USD), tea (12.68 million USD), footwear (34.11 million USD), processed fish ( 12 million USD), furniture (7 million USD), copra (67.83 million USD), plastics and derivatives (14.1 million USD), resin (2.6 million USD), paper (9.6 million USD), spices (77 thousand USD) (UN Comtrade, 2018). In the calculation of this commodity alone, the foreign exchange that came out could be saved around 714.057 million USD or $62 \%$ of the purchase value of the Sukhoi SU-35, because the aircraft would be exchanged for commodities owned by Indonesia. Moreover, some of the commodities exported are superior plantation commodities. This is not to mention the multiplier effect arising if the amount above is an additional amount beyond that normally imported by Russia, then there is an additional export worth 714 million to the Russian market, and of course, producer income will increase by that too.

Optimizing the export of plantation commodities, especially those managed by the people, must be considered several things, including aspects of the production process. For example in the palm oil commodity, CPO importing countries will not buy CPO produced in Indonesia if the CPO produced comes from unsustainable palm oil plantations (Lestari et al., 2015). As the RSPO report (2014) to date, only global palm oil has sustainable governance and certification. The palm oil industry, specifically the world's palm oil plantations since 2006, has had sustainable governance and certification initiated by the Roundtable Sustainable Palm Oil (RSPO). Then since
2011, the government has also implemented governance and certification of sustainable palm oil plantations, namely Indonesia Sustainable Palm Oil (ISPO). Therefore, ISPO as a sustainable palm oil management policy needs to be promoted by the Government throughout the world. The ISPO policy also needs to be made part of Indonesia's international palm oil trade diplomacy. The government needs to convince the world community that Indonesian palm oil is produced by implementing sustainable palm oil governance principles. Then this requires the commitment of palm oil entrepreneurs in sustainably managing palm oil plantations, including smallholders.

At present, smallholders manage around 40 percent (5.6 million hectares) of oil palm plantations in Indonesia with productivity almost 50 percent lower than oil palm plantations owned by private companies (Soliman et al., 2016). So that intensification can be part of efforts to increase the productivity of smallholder plantations by considering the high inequality between the productivity of smallholder plantations and private company plantations. One of the intensification efforts undertaken is the rejuvenation of the people's oil palm plantations. The rejuvenation program is considered important because currently, 2.4 million hectares of 5.6 million hectares of community oil palm plantations are less productive. Of the 2.4 million hectares of the plantation, 2.1 million hectares are indicated as young plantations (less than 25 years in operation) that use low-quality seeds, while the remaining 300,000 hectares are old plantations ( $>25$ years operation) that are no longer productive (Saleh et al., 2019). This method can also be implemented in other plantation commodities that have problems with products such as coffee.

Provision of supporting facilities and infrastructure for plantations can also be done as part of efforts to optimize the export of selected commodities. With adequate infrastructure, plantation products can be produced in sufficient quantity and quality for export. As is the case with community oil palm commodities, there is a Ministry of Agriculture program with the Palm Oil Plantation Fund Management Agency as an agency tasked with managing and channeling program funds. The program aims to increase the production, productivity, and quality of people's palm products by distributing aid in the form of money, goods, or services to farmer groups or other institutions of oil palm planters approved by the government. Assistance can be used to buy seeds, fertilizers, pesticides, postharvest equipment and produce processing, make 
garden roads and access to public roads and/or ports, and buy or rent transportation equipment and agricultural machinery.

Also, the determination of quality standards set by partner countries is also important to consider. Mainly because the selected commodities to be traded are agricultural commodities, various regulations regarding the maximum limit of residues from pesticides, quality levels, sizes, and weights must also be of concern to smallholders. With a high level of quality, the selling price received by the planters will also be high. To encourage exports of agricultural products, the use of electronic certificates (e-Certs) has also been applied, although only to several countries. Since its enactment in 2015, the use of e-Cert has only been carried out in 3 countries namely New Zealand, Australia, and the Netherlands, and added to Vietnam starting July 1, 2019. The advantage of using e-Cert for example, Indonesian agricultural commodities that have been exported have received certainty beforehand. to the destination country before departing. It is different from manual certificates that are brought with exported products, so if there is a refusal, then the goods must be re-exported.

Last is downstream, for example, regulated by Minister of Finance Regulation (PMK) No. 75/PMK.011/2012 along with other policies related to providing facilities in the development of the processing industry. The impact of the imposition of export costs, the value of cocoa exports in the form of seeds continues to decline and vice versa exports of processed cocoa, such as cocoa powder, cocoa butter, cocoa paste and chocolate continue to increase. The growth of the processing industry is also expected to increase multiplier effects, namely absorbing Indonesian workers and mobilizing other related sectors, such as transportation, trade, services, etc.

\section{CONCLUSION}

In conclusion, Indonesia's superiority in producing selected plantation products must be utilized to maintain its position as top producers and even top exporters in the world market. About trade returns, it is known that defense equipment is generally of high value so that agricultural commodities exchanged must also be able to compensate by producing high selling values. Plantation-based industrial development must be carried out by continuing to develop product derivatives to obtain high added value. Also, the quality of selected commodities must be considered in a series of production processes, ranging from pre-harvest conditions, for example by replacing old plants, production conditions about environmental friendliness, to post-harvest such as commodity certification. With optimal exports, the benefits obtained are not only in terms of meeting the needs of alustsista or improving the trade balance but on a micro-scale it is expected to improve the welfare of the people especially in the field of smallholder agriculture.

The trade-off scheme is one of the schemes that can be applied in the procurement of defense equipment from abroad because of the potential to generate various economic opportunities, especially increasing exports of domestic products. This is in line with the existing laws and regulations in Indonesia. The defense system has been regulated in the Government Regulation Number 76 of 2014 concerning the mechanism of Trade Return in the Procurement of Foreign Defense and Security Equipment Tools and the Minister of Defense Regulation Number 30 of 2015 concerning Trade Returns, Local Content, and Offset in the Procurement of Foreign Defense and Security Equipment Tools, in which both of which are referred to as Trade Returns, are reciprocal trade activities between Indonesia and foreign parties measured in the contract value of the procurement contract for defense and security equipment.

\section{REFERENCES}

A. Giles, J., \& Williams, C. L. (2000). Export-led growth: a survey of the empirical literature and some non-causality results. Part 1. The Journal of International Trade \& Economic Development, 9(3), 261-337. https://doi.org/10.1080/09638190050086177

Arifin, Z., Suman, A., \& Khusaini, M. (2020). Countertrade Mechanism of Global Arms Trade: Case Study of Indonesia. International Journal of Financial Research, 11(1), 307-317. https://doi.org/10.5430/ijfr.v11n1p307

Auboin, M. (2004). The trade, debt and finance nexus: at the crossroads of micro-and macroeconomics (No. 6). WTO Discussion paper.

Avila, C. F. D., Souza, D. R. D., \& Guedes, M. A. (2017). Arms transfer policies and international security: The case of Brazilian-Swedish co-operation. Contexto Internacional, 39(1), 135-156.

https://doi.org/10.1590/s0102-8529.2017390100007

Bangun, R. H. B. (2017). Kajian Potensi Perkebunan Rakyat di Provinsi Sumatera Utara Menggunakan Location Quetiont dan Shift Share. Jurnal Agrica, 10(2), 103-111. https://doi.org/10.31289/agrica.v10i2.1159

Barker, A. T., \& Kaynak, E. (1992). An empirical investigation of the differences between initiating and continuing exporters. European journal of marketing, 26(3), 27-36. https://doi.org/10.1108/EUM0000000000638

Central Bureau of Statistics. (2018a). Results of the 2018 Inter Census Agriculture Survey (SUTAS), Series A2. Jakarta: Central Bureau of Statistics

Central Bureau of Statistics. (2018b). Indonesian Rubber Statistics 2018. Jakarta: Central Bureau of Statistics 
Central Bureau of Statistics. (2018c). Indonesian Coffee Statistics 2018. Jakarta: Central Bureau of Statistics

Central Bureau of Statistics. (2018d). Indonesian Tea Statistics 2018. Jakarta: Central Bureau of Statistics

Crick, D., Chaudhry IV, S., \& Batstone, S. (2000). Revisiting the concentration versus spreading debate as a successful export growth strategy: the case of UK SMEs exporting agricultural-related products. Entrepreneurship \& Regional Development, 12(1), 49-67. https://doi.org/10.1080/089856200283081

Czinkota, M. R. (2002). Export promotion: a framework for finding opportunity in change. Thunderbird international business review, 44(3), 315-324. https://doi.org/10.1002/tie.10021

Czinkota, M. R. (2002). Export promotion: a framework for finding opportunity in change. Thunderbird international business review, 44(3), 315-324. https://doi.org/10.1002/tie.10021

Donoso, G. (2016). Chilean agricultural export promotion experience to advance agricultural trade: legal, regulatory and operational frameworks and impact assessment. FAO, Tech. Rep.

Fletcher, R. (1996). Network theory and countertrade transactions. International Business Review, 5(2), 167-189. https://doi.org/10.1016/0969-5931(96)00004-2

Greenaway, D., \& Kneller, R. A. (2004). New perspectives on the benefits of exporting. Economie internationale, (4), 99-110.

Halbach, A. J., \& Osterkamp, R. (1989). Countertrade with developing countries: New opportunities for North-South trade?. Intereconomics, 24(1), 17-23. https://doi.org/10.1007/BF02928544

Harrison, A., \& Rodriguez-Clare, A. (2010). From hard to soft industrial policies in developing countries.

Hennart, J. F., \& Anderson, E. (1993). Countertrade and the minimization of transaction costs: an empirical examination. JL Econ. \& Org., 9, 290.

Hidayat, R. (2013). Analisis Komoditas Unggulan Sub Sektor Perkebunan di Kabupaten Bengkayang Provinsi Kalimantan Barat. Jurnal Social Economic of Agriculture, 2(1). https://doi.org/10.26418/j.sea.v2i1.5119

Jensen, K., \& Davis, G. (1998). An analysis of export market strategies and barriers perceptions by US agricultural HVP exporters. The International Food and Agribusiness Management Review, 1(4), 509-524. https://doi.org/10.1016/S1096-7508(99)00007-5

Kedia, B. L., \& Chhokar, J. (1986). Factors inhibiting export performance of firms: an empirical investigation. Management International Review, 33-43.

Lee, J., \& Habte-Giorgis, B. (2004). Empirical approach to the sequential relationships between firm strategy, export activity, and performance in US manufacturing firms. International Business Review, 13(1), 101-129. https://doi.org/10.1016/j.ibusrev.2003.05.003

Lestari, E. E., Hutabarat, S., \& Dewi, N. (2015). Studi Komparatif Perkebunan Kelapa Sawit Rakyat Pola Plasma dan Pola Swadaya dalam Menghadapi Sertifikasi RSPO. Sorot, 10(1), 81-98.

https://doi.org/10.31258/sorot.10.1.3206

Listyati, D., Wahyudi, A., \& Hasibuan, A. M. (2014). Penguatan kelembagaan untuk peningkatan posisi tawar petani dalam sistem pemasaran kakao. Jurnal Tanaman Industri dan Penyegar, 1(1), 15-28.

https://doi.org/10.21082/jtidp.v1n1.2014.p15-28

Manalu, R. (2018). Pengolahan Biji Kakao Produksi Perkebunan Rakyat untuk Meningkatkan Pendapatan Petani. Jurnal Ekonomi dan Kebijakan Publik, 9(2), 99-112. https://doi.org/10.22212/jekp.v9i2.1006

Ministry of Industry. (2007). Overview of the Cocoa Industry. Jakarta: Secretariat General of the Ministry of Industry.

Moini, A. H. (1997). Barriers inhibiting export performance of small and medium-sized manufacturing firms. Journal of Global Marketing, 10(4), 67-93. https://doi.org/10.1300/J042v10n04 05

Morrissey, O., \& Filatotchev, I. (2000). Globalisation and trade: the implications for exports from marginalised economies. Journal of Development Studies, 37(2), 1-12. https://doi.org/10.1080/713600066

Naidu, G. M., \& Rao, T. R. (1993). Public sector promotion of exports: a needs-based approach. Journal of Business Research, 27(1), 85-101. https://doi.org/10.1016/0148-2963(93)90017-J

Ngaruko, F. (2003). Agricultural export performance in Africa: Elements of comparison with Asia. ESA Working Paper No. 03-09 June 2003.

Nuryati, R., Sulistyowati, L., Setiawan, I., \& Noor, T. I. (2018) Keragaman Pola tanam polikultur perkebunan rakyat sebagai kearifan lokal di kabupaten tasikmalaya.

Pierre, A. J. (2014). The global politics of arms sales. Princeton University Press. https://doi.org/10.1515/9781400854271

Reisman, A., Fuh, D. C., \& Li, G. (1988). Achieving an advantage with countertrade. Industrial Marketing Management, 17(1), 55-63. https://doi.org/10.1016/0019-8501(88)90027-2

Roundtable on Sustainable Palm Oil Impacts Report 2014. (2014). RSPO

Shoham, A., \& Albaum, G. S. (1995). Reducing the impact of barriers to exporting: A managerial perspective. Journal of International Marketing, 3(4), 85-105. https://doi.org/10.1177/1069031X9500300410

Soliman, T., Lim, F. K. S., Lee, J. S. H., \& Carrasco, L. R. (2016) Closing oil palm yield gaps among Indonesian smallholders through industry schemes, pruning, weeding and improved seeds. Royal Society open science, 3(8), 160292. https://doi.org/10.1098/rsos.160292

Stoian, M. C., \& Rialp-Criado, A. (2010). Analyzing export behavior through managerial characteristics and perceptions: A multiple case-based research. Journal of Global Marketing, 23(4), 333-348. https://doi.org/10.1080/08911762.2010.504522

Sultanuzzaman, M. R., Fan, H., Mohamued, E. A., Hossain, M. I., \& Islam, M. A. (2019). Effects of export and technology on economic growth: Selected emerging Asian economies. Economic research-Ekonomska istraživanja, 32(1), 25152531.

https://doi.org/10.1080/1331677X.2019.1650656

Tambunan, T. T. (2004). Globalisasi dan Perdagangan internasional. Bogor: Ghalia Indonesia.

Received on 15-01-2021

Accepted on 24-02-2021

Published on 03-03-2021

\section{https://doi.org/10.6000/1929-4409.2021.10.67}

(C) 2021 Arifin et al.; Licensee Lifescience Global.

This is an open access article licensed under the terms of the Creative Commons Attribution Non-Commercial License (http://creativecommons.org/licenses/by-nc/3.0/) which permits unrestricted, non-commercial use, distribution and reproduction in any medium, provided the work is properly cited. 